\title{
Handling Entrepreneurship in Tertiary Institutions in Nigeria
}

\author{
Ama Aka Udu ${ }^{1}$ \\ ${ }^{1}$ Ebonyi State University, Abakaliki, Nigeria \\ Correspondence: Ama Aka Udu, Business Management Department, Faculty of Management Sciences, Ebonyi \\ State University, Abakaliki, Nigeria. E-mail: amanneudu@yahoo.com
}

Received: August 28, $2013 \quad$ Accepted: October 30, $2013 \quad$ Online Published: February 25, 2014
doi:10.5539/jms.v4n1p189

\begin{abstract}
The paper uses eclectic entrepreneurship theories to identify and develop strategies aimed at creating passion and arousing entrepreneurial interests among Nigerian academics and graduates. The concern of the paper stems from the fact that most graduates of Nigerian tertiary institutions are seen milling around private and public establishments seeking for both solicited and unsolicited job opportunities as if being self employed is a crime. The University and the academics hardly look outside the box to see investment and research yearning opportunities that could robustly create streaming funding. The paper sees entrepreneurship as the process of generating sound investment ideas and the applications thereof. Consequently, entrepreneurs are discussed as those who exhibit rare and sound investment ideas and who characteristically take the ideas to the industry where values are infused. Descriptive survey design using conversation and discourse analyses was adopted. The major finding of the paper is that there is significant lack of a workable model that reflects the Nigerian ecosystem in terms of appropriately utilizing academic intellectual potentials and as well inculcating entrepreneurial spirits into the undergraduates at all levels. The implication of this is that graduates leave the university system without a vision and /or an idea of how to create job opportunities. As a result of the findings, the paper suggests the establishment of incubation centers, entrepreneurship clubs, role model interactions and mentoring among others in the tertiary institutions in Nigeria.
\end{abstract}

Keywords: entrepreneurial interests, job opportunities, value creation, wealth creation, tertiary institutions

\section{Introduction}

Given the level of unemployment and underemployment in Nigeria especially among the youths, the Nigerian tertiary educational system can no longer be insensitive in developing strategies and methods aimed at promoting entrepreneurship culture. Tertiary institutions are established on the threshold of teaching, learning, research and community development. To be seen to live up to expectations in these teething period of unemployment and underdevelopment, the educational system and indeed, the academics need to boost entrepreneurship through arousing the entrepreneurial spirits of the students, creating their passion for self dependence and as well improving employment and developing the economic sector and encouraging social cohesion. This has become necessary especially as the BRICS (Brazil, Russia, India, China and South Africa) have shown that economic prosperity and the level of entrepreneurship development a nation attends have a linear relationship. Cohesion are effective engine for natural economic develop and social entrepreneurship activities.

In studies conducted by Crijns \& Vermeulen (2007) and Cuervo et al. (2007), it was observed that entrepreneurship and the progress of any economy are difficult to separate. To join the league of emerging economies, the tertiary institutions have the challenge to intervene - socially and economically. The intervention calls for new technology, indigenous methods of entrepreneurship development, different approach to thinking, a new world view, indeed a new paradigm in learning, teaching, research and community development. The indigenous approach is able to identify and focus on institutional and regional strengths, weaknesses, opportunities, and threats in the context of the Nigerian environment, develop an operational model with and for the local environment. This will no doubt arouse and create the required passion for entrepreneurship development with its concomitant effect of lifting the Nigerian nation state away from the doldrums of poverty and underdevelopment as jobs are created and the economy becomes globally competitive.

However, considering the Nigerian economic environment and her educational system the contentious issue will be do we need generic research or modularize research approach in order to achieve the expected result. 


\section{Entrepreneurship Theory}

Every practice depends on a theory. Entrepreneurship theory, therefore, attempts to present in a concerted manner loose facts about creating, sustaining and expanding existing organizations and/or entrepreneurs. As a result, we need theories of entrepreneurship in order to understand how entrepreneurship works. We need it to save time and cost and to avoid beating about the bush in search of information. We need to understand how things and events are related and to appreciate probable direction of casualty. Without useful information which can be obtained from a good theory, without knowledge of how variables can be related without forecasts in respect of what may happen when elements are either positive or negative and with no predictions in respect of timing and sequencing of events which good theories can provide entrepreneurial efforts will neither be efficient nor practical. They will rather be waste of energies and resources. Success in such a game of blind pursuit will be a matter of luck.

Entrepreneurship theory focuses on psychological, sociological, economical theories among others. A psychological theory, for instance, recognizes traits, motives and personalities as the major factors that instill the entrepreneurial spirit in an individual. Psychologists believe that there is an inner urge or force in a man that makes him desire a change of status and position. Those identified with the psychological theory are Joseph Schumpeter (1934), David McClelland (1961) and Hagen Everett (1963). The sociological theory is of the view that a person's environment is the major motivating factor for entrepreneurship and that ideas, traits, and motives are not enough on their own for entrepreneurship to manifest. Simply put, an individual's sociological background acts as a push factor in the social context of entrepreneurship. In other words, entrepreneurs are created by social, cultural, political, legal and religious variables found in the society. Some scholars associated with sociological theory of entrepreneurship are Max Weber (1949), Thomas Cochran (1965) and Frank Young (1971). The economic theory of entrepreneurship is made up of scholars who see reasons for people becoming entrepreneurs as purely economical emphasizing the principles of demand and supply. Some of such scholars are G.F. Pananek (1965), J.R. Haris (1967) and Kozo Yanamura (1968).

And eclectic knowledge of these theories helps scholars, students and practitioners to be better equipped in becoming entrepreneurs irrespective of conditions, situations, prevailing environments, learning and discipline. Since every practice depends on a theory, it is imperative that students are exposed to these theories using experiential teaching and learning approach. A good result in this regard will be achieved when entrepreneurs who have identified in any of the theories or combinations thereof are allowed to talk to the students on their success stories.

\section{Concept of Entrepreneurship}

Entrepreneurship is anchored on ideation; applicable ideas. It is all about generating ideas that are applicable, economic and commercial in nature in the entire gamut of human endeavor. Sound ideas that positively propel the economic, political and socio-cultural development of communities, states and nations are the hallmark of entrepreneurship. Entrepreneurship is about generating ideas that are used in creating new firms, new jobs, new relationships, new methods of production and as well new methods of doing things and/or modifying existing ones so as to enhance their value. Entrepreneurship activities, therefore, focus on value enhancement. In separate seminal papers done by Knight (1967), Druker (1970), Davarajan and Ray (2006) and Hisrich, Peter and Shepherd (2008), there is a commonality that entrepreneurship as a process is anchored on creating wealth through value creation. Nayab (2011) asserts that entrepreneurship is the creation of new economic entity centered on a novel product or service or, at the very least, one which differs significantly from the products or services offered elsewhere in the market.

However it is conceptualized, entrepreneurship centres on wealth and value creation. Wealth and value are actually created through creative and innovative processes. Creativity brings into focus the existence of abstract knowledge/phenomena whereas innovation exists to transform the abstract knowledge/phenomena into reality and take it to the society whose need problem it solves. Therefore tertiary institutions in Nigeria are to queue into the wealth and value creation through ensuring that students are equipped with creative and innovative skills sufficient enough to imbue in them confidence in the pursuit of economic activities, in developing policies, in analyzing economic activities and environments, in seizing business opportunities, in developing new products, new services new markets and indeed leadership acumen. Agu (2010) agrees with this view when he observed that entrepreneurs keep their eyes open and active to identify and seize opportunities.

Entrepreneurship development seems to have been prodding on a tripod like-sociological, psychological and economical. Though the tenets of the triad may differ but the commonality remains that of wealth and value creation and distribution. Whichever angle one looks at it entrepreneurship is a process through which values are 
created and wellbeing of mankind is enhanced and those who drive the process are called entrepreneurs. Entrepreneurs are hardworking, focused and purposeful. Therefore, entrepreneurs see every failure as a stepping stone to success. Crisis comes with latent opportunities which entrepreneurs are able to exploit. Entrepreneurs are persons rather than processes who are willing and are able to identify business opportunities, analyze and mobilize resources so as to solve such societal needs while satisfying themselves. In other words failure does not distract entrepreneurs. A good entrepreneur takes advantage of every situation.

An entrepreneur is an effective planner, organizer, director, controller, imaginator, originator, creator, innovator, a person who is always apt with sound ideas on how to challenge and change economic, social, psychological and even ecological failures. To the entrepreneur, there is a potential treasure in every seeming failure or challenge, the value of which worth the risk therein.

Consequent upon the foregoing, therefore, there exists a distinguishing feature between corporate entrepreneurs and managers. Whereas the corporate entrepreneur posses the aforementioned features, the manager is comfortable with the first four features (planning, organizing, directing and controlling) and does it so routinely that he waits for the entrepreneur to initiate before he comes in. From this distinction, it is noted that entrepreneurship goes beyond the boundaries of just having a business firm or overseeing its affairs, it is not being a billionaire without a corresponding economic, social, psychological or ecological activities, and it is not being a contractor patronized by ones political party only. Entrepreneurs are not manipulators and/or gamblers. They are those who see visions and translate their visions into social, economic and commercial activities that are capable of enhancing the well-being of the citizens. Indeed they are persons with over-ridding will to engage in economic and commercial activities that are of benefit to the society, without regard to the difficulties encountered. They are debtors whose cause of debt is investment driven.

\section{Entrepreneurship Education}

Entrepreneurship Education started over a century with Harvard University offering the first graduate course in entrepreneurship in 1947 (Katz, 2003). Since then the field has been expanding with several researches conducted in different aspects of the discipline. In Nigeria, entrepreneurship education is dominated by technical and vocational education that distances itself from entrepreneurial ideologies of value and wealth creation. This approach confirms McMullam et al. (2001) view that entrepreneurship education has not done much to establish its impact on the development of entrepreneurial skills and values even though economic dynamisms have created needs for practical entrepreneurial orientation tailored to societal demands.

In order to properly situate entrepreneurship education in Nigeria, the Federal Ministry of Education directed higher institutions to mount and run general studies and Bachelor of Science degree on entrepreneurship. With the directive, there exist different types of approaches in the teaching of entrepreneurship in Nigeria with the majority taking entrepreneurship as being skill acquisition. Since the two concepts do not mean the same both in philosophical underpinnings and practices, entrepreneurship educators, therefore, need to convoke and set a definite agenda for inculcating entrepreneurial skills and indeed attitudes to the students rather than approaching it atomistically. Such convocation no doubt is bound to raise the issues of the possibility of teaching entrepreneurial skills and attitudes and how best to approach it.

\section{Possibility of Teaching Entrepreneurial Skill}

Higher institutions are established to help societies and individuals to acquire knowledge and develop their inherent potentials. Such potentials do remain inactive until they are energized through conscious education. By implication all human beings are created with some inherent degrees of potentials. What distinguishes one from another is the extent the latent potentials are developed through formal and/or informal education and used in value addition and wealth creation. Individuals with great passion to add value and create wealth do drive economic activities and create job opportunities. They learn and develop new technologies, new markets, new values, new services, and new relationships; in fact they are in state of flux with newness. This means they learn everything new and this is why Drucker (1993) said that entrepreneurship is a discipline that can be learned.

However, its learning requires sound environmental conditions-where sound environment stands for availability and affordability of infrastructure, high quality education, citizens with high moral rectitude, security of lives and property, functional banking system, institutionalization of entrepreneurial culture and above all where corruption is not celebrated.

Therefore, it is crucial to encourage entrepreneurship education through entrepreneurship culture and as well through economic policy instruments. Such culture and policy will aim at identifying the present and future needs of the students and develop an appropriate academic curriculum that will endear it. The approach as 
proposed, calls for retooling of the academic curriculum embedding in it experiential approaches so as to queue into the present and potential needs of students and society.

\section{What and How to Teach}

It is important that what to teach is generally discussed. The agenda setting should be able to clarify whether the teaching adopts generic or modularize approach given the peculiarities of the environment. However, given the influence of globalization on all economies, generic approach becomes the ultimate. Globalization calls on employees especially potential ones to be equipped with diverse skills and attitudes that are not environmentally bound. Simply, the teaching should cover and focus on such skills as should expose the students to critical thinking, idea generation, self discipline, self concept, financial discipline, environmental scanning competencies, conceptual, technical and human relational ones. Leadership and team spirit skills are essential.

Having agreed that entrepreneurship skills and attitudes can be taught and as well identified the appropriate skills and attitudes to be taught, it is imperative, therefore, that how to teach forms part of the agenda setting. More so as research and practice indicate that didactical approach used in handling most general courses does not have the wanted results. The traditional approach of read and explain devoid of personal relationship, team work and collective development of ideas and processes has failed to produce the required results. To this end, Marques and Albuquerque (2012) citing Dolabela (1999) present the divide between the traditional and entrepreneurial teaching approaches as table 1 depicts.

Table 1. Traditional pedagogy versus entrepreneurial pedagogy

\begin{tabular}{ll}
\hline Traditional & Entrepreneurial \\
\hline Emphasis on the content as a purpose & Emphasis on the process (learning to learn) \\
Led and dominated by the teacher & Appropriation of the learned subject by the participant. \\
The knowledge is conveyed by the teacher & The teacher facilitates the discovery and learning \\
The knowledge is acquired and unaffected & The knowledge can change \\
Curriculum and highly planned session & Flexible sessions and targeted to needs \\
Imposed education objectives & Learning objectives negotiated and evolving \\
Priority for the performance & Priority to self-development which generate performance \\
Convergent thinking, rejects conjectures & Divergent thinking and assumptions as part of the creative process \\
Emphasis on analytical and linear thinking & Holistic thinking strategies \\
Theoretical and abstract knowledge & Theoretical knowledge together with practical application \\
Resistance to the influence of the community & Encouraging the communities influence \\
Emphasis in the outside world & The inner experience is a source of learning; feelings are embedded \\
& the action \\
Education as a social necessity for performance of a particular role & Education as a lifelong process, and only barely related to school \\
Errors are not accepted & Error is a sources of knowledge ("good mistake") \\
Knowledge is the bond between teacher and student. & Relationship is the key link between teacher and student \\
\hline
\end{tabular}

Source: Adapted from Dolabela,(1999) as quoted in Marques and Albuquerque (2012).

Entrepreneurial teaching approach enables the students to think outside the box, question the value contents of existing technologies, develop the ability to efficiently scan the environment and identify business opportunities. The teacher plays an advisory role guiding the students towards understanding the ideas they have espoused, supporting and encouraging the correction of mistakes made in the course of idea development and application.

The foregoing paragraph presupposes that entrepreneurial teaching is not aimed at inculcating specific skills, directing and limiting students on the specific knowledge to acquire and as well making learning classroom bound. It goes beyond that to seek exploratory and applicable knowledge, self confidence, risk taking ability as well as creative, imaginative and innovative abilities. Above all it creates single mindedness in anything that fascinates the interest of the student.

\section{Who and When to Teach}

It is important to streamline the profiles of those to be engaged in the teaching of entrepreneurship as the teacher plays a crucial role in the overall effectiveness of any entrepreneurial learning programme. A combination of the knowledge of experiential pedagogy and business mentoring is required. A team approach in which several aspects of entrepreneurial mind will be developed and handled by different experts with requisite knowledge in 
classroom theory and others with experiential knowledge and skill taken concurrently as not to create any gap in appreciating the core values of entrepreneurial spirit. A talk from practicing entrepreneurs creates possibilities of joining them and opportunities of mentorship.

Anybody can be an entrepreneur irrespective of age and discipline, therefore, students at all levels need entrepreneurship education. The important thing as previously stated is that the teaching approach is able to arouse the entrepreneurial interests of the students and create their passion for it. The teaching can take place anytime but better result may be achieved when started at the post primary level.

\section{Conclusion}

In the past, Nigerian educational system did not pay much attention to the handling of entrepreneurship education. Esoteric and modularize approaches were used in the handling of entrepreneurship education. As a result only few individuals and higher institutions showed interest. The few that showed interest partly misconstrued entrepreneurship and didactically taught it as most other general subjects can or should be taught-listen and take notes approach. The current level of consciousness in entrepreneurship education is a welcome development but needs immediate agenda setting to be sustained. The universities should encourage multidisciplinary entrepreneurship clubs formation - the gathering and networking of students with related felt need and world view. Incubation centers of medium standard will provide a good platform for the students and staff to test the feasibility and viability of any germane idea generated either in the clubs or through networks under the guidance of experts. There is a need for the inclusion of entrepreneurs (mentors and role models) in the teaching of entrepreneurship in tertiary institutions. However, analytical studies in the field are welcome.

\section{References}

Agu, R. A. (2010). Frontiers of Entrepreneurship: concepts, theories and practice. Nigeria, Onitsha: Kawuriz and Manilas Publishers Ltd.

Crijns, H., \& Vermeulen, S. (2007). Survey—How entrepreneurial are our Flemish students? Leuven, Vlerick Leuven Gent Management School. Retrieved from http://www.guesssurvey.org/PDF/flandersdc_how_entrepreneurial_are_the_flemish_students.pdf

Cuervo, A., Ribeiro, D., \& Roig, S. (2007). Entrepreneurship-concepts, theory and perspective. Berlin: Heidelberg.

Dolabela, F. (1999). O segredo de Luísa. São Paulo: Editora de Cultura.

Drucker, P. (1970). Entrepreneurship in Business Enterprise. New York: Harper and Row.

Drucker, P. (1993). Innovation and Entrepreneurship (1st ed.). New York: Collins.

Hisrich, R. D., Peters, M. P., \& Shephered, A. D. (2008). Entrepreneurship (7th ed). Singapore: McGraw-Hill.

Katz, J. (2003). The Chronology and Intellectual Trajectory of American Entrepreneurship Education 1876-1999. Journal of Business Venturing, 18, 283-300. http://dx.doi.org/10.1016/S0883-9026(02)00098-8

Knight, K. (1967). A Descriptive Model of the Intra-Firm Innovation Process.

Marques, L. A., \& Albuquerque, C. (2012). Entrepreneurship Education and the Development of young people life competences and skills. ACRN Journal of Entreprenuership Perspectives, 1(2), 55-68.

McClelland, D. C. (1961). The Achieving Society Van Nostrand Reinhold.

McMullan, W., Chrisman, J., \& Vesper, K. (2001). Some problems in using subjective measures of effectiveness to evaluate entrepreneurial assistance programs. Entrepreneurship Theory and Practice, 26(1), 37-54.

Nayab, N. (2011). History of Entrepreneurship. Retrieved from http://www.brighthub.com/office/entrepreneurs/articles/73851.aspx

Ramachandran, K., Davarajan, T. P., \& Ray, S. (2006). Corporate Entrepreneurship: How? Working Papers Series, Indian School of Business.

Schumpeter, J. A. (1934). The theory of Economic Development. Cambridge mass: Havard University.

\section{Copyrights}

Copyright for this article is retained by the author(s), with first publication rights granted to the journal.

This is an open-access article distributed under the terms and conditions of the Creative Commons Attribution license (http://creativecommons.org/licenses/by/3.0/). 